高分子論文集 (Kobunshi Ronbunshu), Vol. 40, No. 10 pp. 661-666 (Oct., 1983)

\title{
スチレンと無水マレイン酸のランダムコポリマーとアクリロニトリルとスチ レンのランダムコポリマーの相容性
}

\author{
加藤 忠哉*1 $・$ 小林 憲明*1 ・ 高橋 彰*1
}

(受付 1983 年 4 月 30 日・審査終了 1983 年 6 月 29 日)

\begin{abstract}
要 旨 スチレンと無水マレイン酸のランダムコポリアー (SMA) とスチレンとアクリロニトリ ルのランダムコポリマー (AS) のコポリマーブレンドの THF 濃厚溶液の光散乱測定を行った。 Debye-Bueche プロット及び Guinier プロットを利用して，コポリマープレンド溶液中の相関距離 及び慣性半径の測定を行った，更に眼視法によるにごりの検出により，相分離潄度の組成依存性及び キャスティングフィルムの透明性を測定して,コポリマーブレンドの相容性について検討した. SMA と AS 両コポリマー中のスチレン含量（モル分率）が類似しているときには, 溶液中及びフィルムに おいて，すぶての混合比で両コポリマーは相容性を示した.
\end{abstract}

\section{1 緒喜}

高分子多成分系材料は種々の材料特性を付与する有効 な手段として広く実用化されている，それに伴って，材 料を構成する高分子-高分子の相容性や相図などの基本 的性質についての研究も理論的・実験的両面から発展し てきた ${ }^{1), 2}$. その中で, 構成成分の異なる 2 種類のコポ リマーの相容性についての系統的実験は比較的少な い゙. またコポリマーブレンドでは多成分系の複雑多様 な相互作用のために，統計熱力学的理論による相容性の 考察は困難とされている.

最近, 青木 ${ }^{4)}$ により，スチレンと無水マレイン酸のラ ンダムコポリマー (SMA と略記) とスチレンとフクリ ロニトリルのランダムコポリマー (AS) のコポリマープ レンドのガラス転移領域に推ける複素弾性率の温度分散 の測定から，SMA の共重合体組成を一定とした場合に AS の共重合体組成のある範囲においてこれらの二つの コポリマーが相容することが見つけられた，実用面で は, AS KSMA をブレンドすることにより材料の耐熱 性を向上させることができるので, 新規の高分子多成分 系材料として注目されている.

本報告は, SMA と AS との相容性を更に詳しく研究 するために, 共通溶媒であるテトラヒドロフラン (THF) を用いて，SMA/AS/THF 系の濃厚溶液 $(0.1 \sim 0.2 \mathrm{~g} /$ $\mathrm{m} l)$ の SMA と AS との相分離及びこの溶液から得ら れるキャスティングフィルムの透明性を測定したもので ある. 濃厚溶液の光散乱測定を行って散乱強度の増加及 び散乱強度の角度依存性から見積った相関距離の不連続

*1 三重大学工学部工業化学科（画514 津市上浜町 1515)
的な急增に基づいて，相分離の有無を判定したら)。 また フィルムについては, 透明性の変化より相容・非相容を 判定した。これらの実験結果から，相容するコポリマー 濃度の範囲及び SMA と相容する AS の共重合体組成 範囲について考察する.

\section{2 実験}

\section{1 試料}

SMA 試料は Arco 社製の Dylark 332 を用いた。 約 5\% のメチルェチルケトン (MEK) 溶液を作り, 沈 殿剤としてn一キキサンを用いて沈殿精製した後, 室温に て1昼夜真空乾燥した.

AS 試料はスチレンモノマー (St) とアクリロニトリ ルモノマー (AN) の混合比を変えて共重合させた組成の 異なる AS-15, AS-20, AS-27 の 3 種類であり, 三菱モ ンサント(株)四日市研究所より恵与されたものである. AS 試料も約 $5 \%$ の MEK 溶液をメタノールに滴下し， 沈殿精製した後, 真空乾燥した.

精製試料の共重合体組成はSMA, AS ともに元素分 析法によりそれぞれ決定した. Table 1 に SMA 試料の 平均組成を無水マレイン酸 (MA) の mol\% にて示し, AS 試料については AN mol\% にて示した。 また精製 SMA について赤外吸収測定を行って，MA の吸収を確 認した。

使用した有機溶媒は半井化学薬品の試薬一級をそのま ま使用した。

\section{2 浸透圧及ひ粘度測定}

試料の数平均分子量 $\left(M_{n}\right)$ 及び第 2 ビリアル俰数 $\left(A_{2}\right)$ の測定は高速膜浸透王計 (Hewlett-Packard 社)を用い, 半透膜は再生セルロース膜 (ザートリウス社製 \#11539), 
溶媒は THF, 測定温度は $30^{\circ} \mathrm{C}$ にて行った。

極限粘度 [ク]はウべローデ希釈型粘度計を用い， $25.00 \pm 0.05^{\circ} \mathrm{C}$ にて測定した. THF の流下時間が $108 \mathrm{~s}$ の粘度計を使用した．運動エネルギー補正及びずり応力 補正は行っていない.

\section{3 光散乱測定}

散乱体積内の波長オーダーの距離にある微小要素間に 分極率のゆらぎがあれば光が散乱され，その還元散乱強 度 $\mathrm{R}(\theta)$ は $r$ だけ離れた要素間のゆらぎの相関関数 $r(r)$

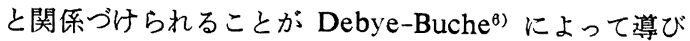
かれた. $\gamma(r)$ は一般に指数関数で近似される.

$$
r(r)=\exp (-r / a)
$$

ここで $a$ はゆらぎの相関距離であり, 散乱能のゆらぎ を〈 $\left\langle\eta^{2}\right\rangle$ と表示すれば，次の関係が得られる

$$
R(\theta)=\frac{8 \pi\left\langle\eta^{2}\right\rangle a^{3}}{\left(1+a^{2} q^{2}\right)^{2}}
$$

ここで $q$ は散乱べクトルの絶対値である.

$$
q=\frac{4 \pi}{\lambda} \sin \left(\frac{\theta}{2}\right)
$$

(2) 式より $R(\theta)^{-1 / 2}$ あるいは $I_{\theta}^{-1 / 2}$ を $q^{2}$ または $\sin ^{2}(\theta / 2)$ にプロットすることにより $a$ を実験的に見積 ることができる．ここで $I_{\theta}$ は散乱角度 $\theta$ における測定 強度である．また $\ln R(\theta)$ または $\ln I_{\theta}$ を $q^{2}$ または $\sin ^{2}(\theta / 2)$ にプロットするいわゆる Guinier プロットか ら慣性半径 $R_{G}$ を得ることができる ${ }^{b)}$ 。このように，ポ リマーブレンド系の $a$ 及び $R_{\mathrm{G}}$ はブレンド系内の構造 的ゆらぎの大小に対応し，また相分離の有無を反映する と考劣ることができる.

測定装置はニニオン技研 (侏) 製の LS601A 自動光散乱 測定装置と測定制御及びデータ処理用のソード社 M223 Mark III マイクロコンピューターを組み合せたもので ある. 光源はアルゴンイオンレーザー (波長 $488 \mathrm{~nm}$ )を 用いた。散乱角度 $10^{\circ} \sim 150^{\circ}$ を $10^{\circ}$ 間隔で測定した。 SMA, AS-15, AS-20 及び AS-27 の濃厚溶液を THF を用いて調整した。これらの原夜を混合して所定の組成 比及び所定濃度の溶液を作った。この溶液をミリポアフ ィルターFH（孔径 $0.5 \mu \mathrm{m}$ ) にてろ過して直接円筒形七 ルに導入した。一つの濃度の光散乱測定を終了した後, 測定七ルをゴミの無い空気恒温槽 $\left(25^{\circ} \mathrm{C}\right)$ に入れ, THF を数時間かけて徐々に蒸発させて溶液を濃縮した，濃縮 後の溶液濃度は, 測定セル中の液柱の減少を読又取り顕 微鏡にて読及取り, 求めた体積減少量から決定した。七 ル中に濃度の不均一が生じないよらにときどき測定セル をかくはんした３倍の濃度にまで測定七ル中で濃縮が 可能であった。 光散乱測定は SMA/AS-15, SMA/AS20 及び SMA/AS-27 の 3 種類の組合せについて, AS 対 SMA の等重量混合の組成のものを濃度を変えて, 測定した. 更に SMA/AS-27 の混合系について, MA/
AN のモル比が $32 / 68,43 / 57,50 / 50$ 及び 58/42 の 4 種 類の組成について測定した。

\section{4 眼視法によるにごりの測定}

MA/AN のモル比で表した組成を細かく変化させて 実験を行らために, SMA とASの 3 種類の組合せの混 合物について，相分離の発現を眼視による “にごり”の 観察から判定する方法を用いた．所定の組成と濃度の溶 液を目盛付き試験管に入れ，空気恒温槽中でときどきか くはんしながら THF を蒸発させて濃縮しつつ,にごり が生ずる濃度を決定した，測定温度が $25^{\circ} \mathrm{C}$ 一定のとき におけるにごりの生ずる濃度と MA/AN のモル比との 関係についての結果をここに報告するが，にごりは濃度 一定のもとでは温度の上げ下げによって可逆的に消失と 出現を繰り返すことが観測されているので，原理的に は, 濃度一定のもとにおいてにごりを生ずる温度 $\mathrm{T}$ 対混 合組成からなる相図を作成することも可能である.

また別に SMA と AS の 3 種類の混合物について, 更に組成を細かく変えて THF 溶夜からキャスティンク 法によってフィルムを作り，その透明性を眼視法で判定 した。

\section{3 結果と考察}

\section{1 試料の分子特性值}

Table 1 に SMA, AS-15, AS-20 及び AS-27 の THF 溶液中 $25^{\circ} \mathrm{C}$ に打唀圧法により測定した $M_{n}$ と $A_{2}$ 及び粘度測定によって得られた $\left.\eta \eta\right]$ を示す。 また参考のために MEK 溶液の光散乱測定から青木に よって見積られた $\left(M_{w}\right)_{\mathrm{app}}$ を示す ${ }^{4)}$. 各試料の分子量と [ク] の值から良溶媒中の Flory-Fox の粘度式 ${ }^{8)}$ を仮定し て $R_{G}{ }^{\prime}$ を推定すると, 溶液中の分子サイズは Table 1 の最後に示す值となり，いずれも $120 \sim 170 \AA$ の範囲に あり，分子サイズは類似している。

\section{2 相関距離と憎性半径の濃度依存性}

Fig. 1 (a) は SMA/AS-15 の等量混合物の DebyeBueche プロットを示す.この系は青木により混練試料 において完全に相容することが観測されている， $I_{\theta^{-1 / 2}}$ 対 $\sin ^{2}(\theta / 2)$ プロットのこう配は測定濃度範囲では变化 していない. Fig. 1 (b) は SMA/AS-27 の等量混合物 のプロットを示す. Fig. 1 (a) と比較して明らかなよう に，低濃度の三つのプロットのこら配はほぼ同じである が, 高濃度側では濃度の増加とともにこう配は增えてい る. 更に Fig. 2 に示すように, SMA/AS-27 の等量混 合物についての Guinier プロットのこう配も高濃度側 で増加している。

3 種類の等量混合物のそれぞれの $a$ 及び $R_{G}$ 值の濃 度依存性を Fig. 3 及び Fig. 4 に示す. SMA/AS-15 及び SMA/AS-20 の混合物については，観測された濃 度範囲では $a$ 及び $R_{G}$ は一定である.一方 SMA/AS- 
スチレンと無水マレイン酸のランダムコポリマーとアクリロニトリルとスチレンのランダムコポリマーの相容性

Table 1. Molecular characteristics of copolymer samples

\begin{tabular}{|c|c|c|c|c|c|c|}
\hline Sample & $\begin{array}{c}\text { Composition } \\
(\text { mol \%) }\end{array}$ & $\begin{array}{c}M_{n} / 10^{4} \\
\left(\mathrm{~g} \mathrm{~mol}^{-1}\right)\end{array}$ & $\begin{array}{c}\mathrm{A}_{2} 10^{4} \\
\left(\mathrm{~mol} \mathrm{~m} \mathrm{~g}^{-2}\right)\end{array}$ & $\left(\begin{array}{l}{[\eta]} \\
\left(l^{\prime} g^{-1}\right)\end{array}\right.$ & $\begin{array}{c}\left(M_{w}\right)_{\mathrm{app}} / 10^{4} \\
\left(\mathrm{~g} \mathrm{~mol}^{-1}\right)\end{array}$ & $\begin{array}{l}R_{G^{\prime}}^{\prime} \\
(\AA \AA)\end{array}$ \\
\hline SMA & $22.9^{\mathrm{a})}$ & 10.6 & 0.79 & 0.851 & 18.5 & 174 \\
\hline AS-15 & $25.2^{\mathrm{b})}$ & 7.65 & 8.96 & 0.751 & 12.8 & 146 \\
\hline AS-20 & $30.1^{\mathrm{b})}$ & 6.71 & 8.48 & 0.741 & 11.0 & 138 \\
\hline AS-27 & $39.8^{\mathrm{b})}$ & 4.81 & 10.5 & 0.612 & 8.8 & 120 \\
\hline
\end{tabular}

a) The copolymer composition in mole\% of maleic anhydride.

b) The copolymer compositions in mole\% of acrylonitrile.

$R_{\mathrm{G}}{ }^{\prime}$, the radii of gyration estimated by the Flory-Fox viscosity equation.

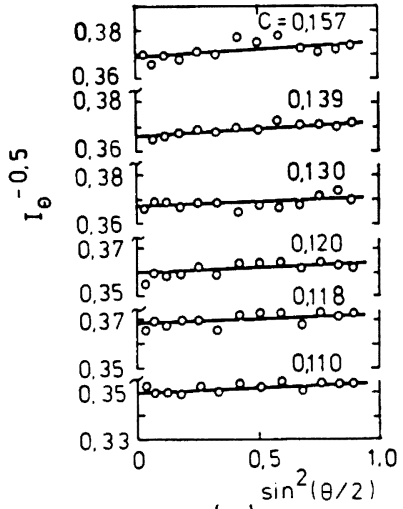

(a)

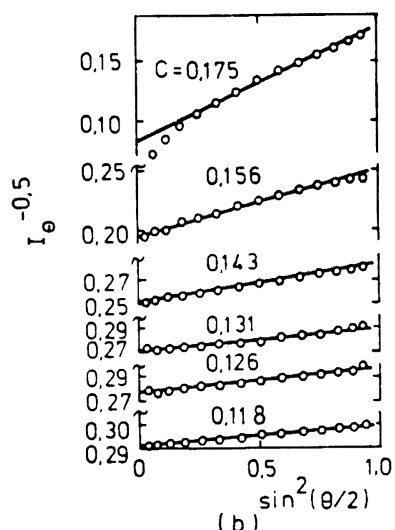

(b)

Fig. 1. Debye-Bueche plots for styrene-maleic anhydride random copolymer (SMA)/acryllonitrile-styrene random copolymer (AS) blends in tetrahydrofuran (THF) at $25^{\circ} \mathrm{C}$. C is the total copolymer blend concentration expressed in $\mathrm{g} / \mathrm{ml}$. (a) Sample: SMA/AS- 15 copolymer blend. The sample is the copolymer blend of SMA and AS-15 with equal weights.

(b) Sample; SMA AS-27 blend.

27 については, 濃度がおよそ $0.14 \mathrm{~g} / \mathrm{ml}$ を越えると $a$ 及び $R_{G}$ が急速に増加する.この高濃度側においては眼 視法によってセル中ににごりが観測されることを考え併 せると, $a$ 及び $R_{G}$ の增加は相分離の結果であると推 測される．したがって， $a$ 及び $R_{\mathrm{G}}$ の濃度依存性が不連 続になる濃度を相分離の開始濃度 $C^{\prime}$ とする. 濃度依存 性のない範围の $a$ 及び $R_{\mathrm{G}}$ の間には $R_{\mathrm{G}}{ }^{2}=6 a^{2}$ の関係が 3 種類の混合物ともに成立しており， $\gamma(r) か ゙(1)$ の式の指 数関数でよく近似できると考学られる. 更に Fig. 4 の 混合物の $R_{\mathrm{G}}$ は SMA/AS-15, SMA/AS-20, SMA/AS27 の順に大きくなっており，SMA/AS-15 では, Table 1 のそれぞれのコポリマーの $R_{G^{\prime}}{ }^{\prime}$ よりも非常に小さい． 試料の分子量と $R_{G^{\prime}}{ }^{\prime}$ から高分子鎖が互いに重なり始め る濃度 $\left(C^{*}\right)$ を見積ると拈およそ $0.08 \mathrm{~g} / \mathrm{ml}$ となり，測 定濃度範囲は準濃厚溶液の領域である゙ ${ }^{0}$ 。したがって， 両コポリマー鎖同志はある程度相互貫入して溶液内の分 極率の不均一さの幅を減少させていると考えられる.こ の観点から, SMA/AS-15, SMA/AS-20, SMA/AS-27の
順序に $a$ 及び $R_{\mathrm{G}}$ が大きくなっていることは，この順 序に相容性が減少すること，更に SMA/AS-27 におい て $C^{\prime}$ 以上では相分離により不均一さが急速に增大する ことを意味する. 混合物中の MA のモル数が 3 種類と も同じであることを考虑して，共重合体組成からそれぞ れの MA/AN のモル比を計算すると，SMA/AS-15 で は 45/55, SMA/AS-20 では 40/60, SMA/AS-27 では 32,68 であった。 そこで MA と AN 間の相互作用が 相容性に影響すると仮定すれば，MA と AN が等モル 存在したときに相互作用が最大効果を現すと考兄られる ので, SMA/AS-27 について MA/AN のモル比を变化 させて光散乱測定を行った.

Fig. 5 (a) は，それぞれの MA/AN のモル比につい て見積られた $a$ の濃度依存性から $C^{\prime}$ を決定し， $C^{\prime}$ を $\mathrm{MA}$ と $\mathrm{AN}$ の総モ儿数中の $\mathrm{MA} の$ 分率 $(=\mathrm{MA} /(\mathrm{MA}$ +AN) と定義する) にプロットしたものである. MA/ AN のモル比が 50/50のとき， $C^{\prime}$ は極大值 $0.161 \mathrm{~g} / \mathrm{ml}$ となった。 


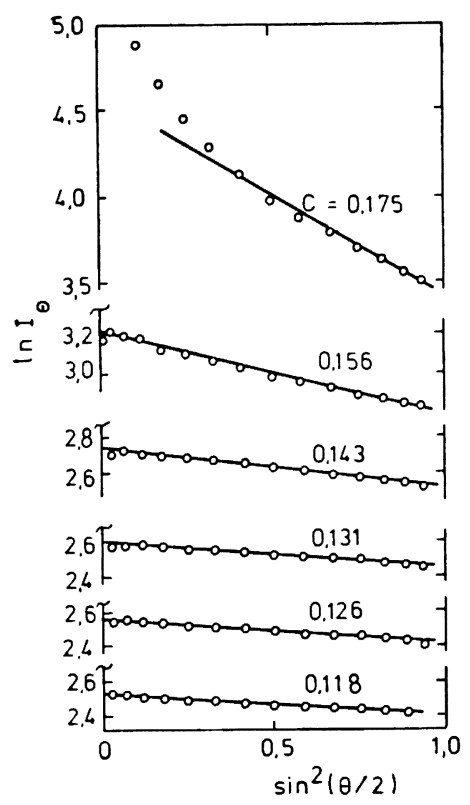

Fig. 2. Guinier plots for SMA/AS copolymer blends in THF at $25^{\circ} \mathrm{C}$. $C$ is the total copolymer blend concentration expressed in $\mathrm{g} / \mathrm{ml}$. The sample is SMA/AS-27 blend, the same as in Fig. 1 (b).

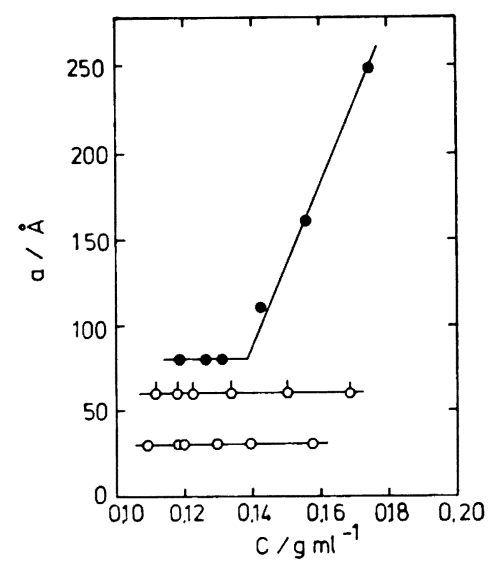

Fig. 3. Correlation distances $a$ in the copolymer blend solutions are plotted against the total copolymer blend concentrations $C$. Samples: upper, SMA/AS-27; middle, SMA/AS-20; lower, SMA/AS-15.

\section{3 溶液とフィルムの透明性}

Fig. 5 (b) は, SMA/AS-27 について眼視法によって にごりが検出され始めた濃度 $C^{\prime \prime}$ を $\mathrm{MA}$ の分率にプロ

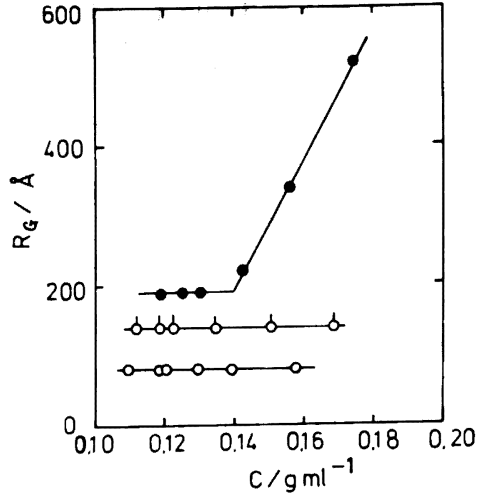

Fig. 4. Radii of gyration estimated by Guinier plots are plotted against $C$. Samples: upper, SMA/AS-27; middle, SMA/AS-20; lower, SMA/ AS-15.

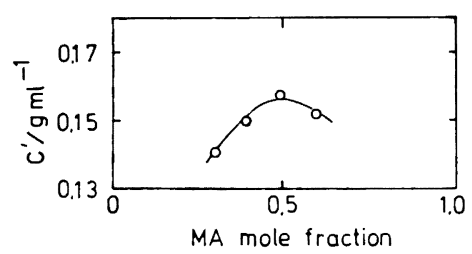

(a)

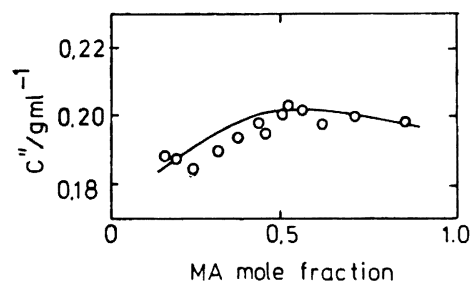

(b)

Fig. 5. (a) Phase separation concentrations $\left(C^{\prime}\right)$ of SMA/AS-27 are plotted against the mole fractions of maleic anhydride (MA) defined as $\mathrm{MA} /(\mathrm{MA}+\mathbf{A N})$, where $(\mathrm{MA}+\mathrm{AN})$ is the total mole number of $\mathrm{MA}$ and acrylonitrile (AN) within the blends. $C^{\prime}$ is the concentration at which the contration dependence of $a$ changes distinctly, as shown in Fig. 3. (b) The concentrations of the cloud point $\left(C^{\prime \prime}\right)$ are plotted against the MA mole fractions.

ットしたもので, Fig. 5 (a) と同じように, MA の分 率が 0.5 にてにごりが検出できる濃度は極大となる.

すなわち, Fig. 5 (a) と Fig. 5 (b) の結果より MA/ ANのモル比の大小が相容性に影響していることがわか り, SMA/AS-27 では MA と AN が等モル存在する ときに最も相容性が大きくなる. 
スチレンと無水マレイン酸のランダムコポリマーとアクリロニトリルとスチレンのランダムコポリマーの相容性

Table 2. Visual observation of transparency of copolymer blend films

\begin{tabular}{|c|c|c|c|c|c|c|}
\hline (1) & SMA/AS-15 Blends & (2) SM & AS-20 Blends & (3) & SMA/AS-27 & Blends \\
\hline $\begin{array}{l}\text { MA mole } \\
\text { fraction }\end{array}$ & $\begin{array}{c}\text { Film } \\
\text { compatibility }\end{array}$ & $\begin{array}{l}\text { MA mole } \\
\text { fraction }\end{array}$ & $\underset{\text { compatibility }}{\text { Film }}$ & & $\begin{array}{l}\text { MA mole } \\
\text { fraction }\end{array}$ & $\underset{\text { compatibility }}{\text { Film }}$ \\
\hline 0.925 & 0 & 0.806 & $\Delta$ & & 0.855 & $x$ \\
\hline 0.755 & 0 & 0.760 & $\triangle$ & & 0.782 & $\times$ \\
\hline 0.628 & 0 & 0.693 & $x$ & & 0.619 & $x$ \\
\hline 0.519 & 0 & 0.550 & $x$ & & 0.500 & $x$ \\
\hline 0.440 & 0 & 0.420 & $\times$ & & 0.430 & $x$ \\
\hline 0.359 & 0 & 0.317 & $x$ & & 0.310 & $\times$ \\
\hline 0.280 & 0 & 0.208 & $\times$ & & 0.195 & $x$ \\
\hline 0.260 & 0 & 0.180 & $\times$ & & 0.134 & $x$ \\
\hline 0.212 & 0 & 0.120 & $x$ & & 0.076 & $x$ \\
\hline 0.105 & 0 & 0.090 & $\Delta$ & & 0.036 & $x$ \\
\hline
\end{tabular}

a) $O$, compatible; $x$, incompatible; $\triangle$, uncertain.

Table 2 はキャスティングフィルムの透明性について 測定した結果を示す。透明なフィルムが得られた場合に は相容性として○印, 判定が不確かなるのを $\triangle$ 印, 完全 ににごって不透明なフィルムを×印で示した，SMA/ AS-15 のフィルムは全組成範囲にて相容性であり, 一 方 SMA/AS-27 のフィルムは全組成範囲にて不透明な フィルムを得たので非相容性と判定した，SMA/AS-20 では，Fig. 3 及び 4 に示したように， $a$ 及び $R_{\mathrm{G}}$ は測 定した濃度範囲内では一定値であり, 溶解状態は相容性 を示したが,フィルムはにごっており，相容性は前述の 二つの混合物の中間にあった.

\section{4 結論}

SMA/AS-15 は溶液でもフィルムでも全組成範囲で相 容性である.SMA/AS-27 は非相容性である.これは青 木の結果と一致する. MA/AN のモル比の調節によっ てある程度相容性を增加できることから， MA と AN の相互作用が相容性に関与しているが，支配的ではな く, 結局はコポリマーの平均組成が相容性を決定してい る.しかしながら，本実験では光散乱測定及び眼視法に よるにごりの観測を相容性の判断規準としているから, 可視光の波長のオーダーの相容性, いいかえれば分子レ ベルのプレンド系の均一性を対照としているが，七グメ ントレペルの完全な “相溶性”については判定できなか った。
謝辞 本研究に当たり，試料をご提供いただいた三 菱モンサント(株) 四日市研究所青木雄二氏に哚く感謝す る。

\section{文献}

1) 高分子学会編, “ポリマーアロイ”, 東京化学同 人 東京 $(1981)$.

2) 秋山三郎, 井上隆, 西敏夫, “ポリマーブレン ド”, シーェムシー, 東京 (1981).

3) S. Krause, "Polymer Blends", Vol. 1, D.R. Paul and S. Newman, Ed., Academic Press, New York (1978) pp. 15-113.

4) 青木雄二, レオロジー討論会要旨集 (1981), p. 125.

5) R. S. Stein, "Polymer Blends", Vol. 1, D.R. Paul and S. Newman, Ed., Academic Press, New York (1978) pp. 393-444.

6) P. Debye and A. M. Bueche, J. Appl. Phys., 20, 518 (1949).

7) P. Debye, H. R. Anderson, and H. Brumberger, J. Appl. Phys., 28, 679 (1957).

8) P. J. Flory, "Principles of Polymer Chemistry", Cornell University Press, Ithaca, N.Y. (1953).

9) P. G. de Gennes, "Scaling Concepts in Polymer Physics", Cornell University Press, Ithaca, N.Y. (1979). 


\section{Compatibility of Styrene-Maleic Anhydride Copolymer with Acrylonitrile-Styrene Copolymer}

Tadaya Kato*1, Noriaki KobaYashi*1, and Akira TaKahashi*1

${ }^{* 1}$ Department of Industrial Chemistry, Faculty of Engineering, Mie University (1515, Kamihama-cho, Tsu, 514 Japan)

Static light scattering measurements were carried out on concentrated tetrahydrofuran solutions of the copolymer blends. The copolymer blends were made of sytrene-maleic anhydride random copolymer (SMA) and acrylonitrile-styrene random copolymer (AS). Using Debye-Bueche plots and Guinier plots, correlation distances $(a)$ and radii of gyration $\left(R_{G}\right)$ were determined from the experimental results of light scattering. The compatibility of the copolymer blends is discussed on the basis of the composition dependences of the phase separation in solutions and in casting films. The phase separation behavior was observed by the visual inspection of the turbidity. If the styrene contents (mole fractions) of both SMA and AS copolymers are nearly equal, the copolymer blends of SMA/AS are compatible over almost the entire composition of the blends.

KEY WORDS Compatibility / Styrene-Maleic Anhydride Copolymer / Acrylonitrile-Styrene Copolymer / Correlation Distance / Static Light Scattering / Debye-Bueche Plot / Copolymer Blends /

(Received April 30, 1983: Accepted June 29, 1983)

[Kobunshi Ronbunshu, 40 (10), 661-666 (1983)] 